\title{
DOI https://doi.org/10.30525/978-9934-26-116-9-40
}

\section{СЛІДЧИЙ СУДДЯ - СУБ'ЄКТ ДОКАЗУВАННЯ?}

\author{
Компанець С. М. \\ аспірант Науково-дослідного інституту інтелектуальної власності \\ Національної академії правових наук України \\ м. Київ, Украӥна
}

Слідчий суддя (далі - CC) новий важливий процесуальний суб'єкт за чинним Кримінальним процесуальним кодексом України (далі - КПК) [1] на стадії досудового розслідування. На СС покладено функцію судового контролю за дотриманням прав, свобод та інтересів осіб у кримінальному провадженні (п.18, ч. 1 ст. 3 КПК). Згідно 3 ч. 3 ст. 26 КПК принцип диспозитивності означає, що СС вирішує лише ті питання, що винесені на його розгляд сторонами та віднесені КПК до його повноважень. Законодавець визначив СС як суб'єкта оцінки доказів (ст.94 КПК). Виходячи з симбіозу понять перевірки та оцінки доказів, як елементів процесу доказування, очевидно, що під час судового розгляду СС виконує функцію дослідження (юридичного пізнання) та оцінки доказів, поданих сторонами.

В науковій літературі повноваження СС поділяють на декілька груп: повноваження при застосуванні заходів процесуального примусу на стадії досудового розслідування; при розгляді скарг на дії та рішення особи, яка здійснює дізнання, слідчого чи прокурора; при проведенні судово-слідчих дій, в т.ч. які обмежують конституційні права людини і громадянина.

Про роль та повноваження СС в процесі доказування науковці багато полемізують. Гловюк І.В. [2], Туманянц А.Р. [3], Удалова Л.Д., Азаров Ю.І., Письменний Д.П. [4] та ін. вважають, що СС є суб'єктом доказування (далі - СД). Низка авторів підтримують таку думку, однак власне обгрунтування не наводять. На відміну від КПК, відповідно до Кримінально-процесуального закону Королівства Іспанія слідчий суддя відповідальний за законність досудового розслідування, однією з його основних функцій та обов'язків $є$ збирання доказів [5, с. 702,713].

Колесник В.А. [6], Горбачевський В.Я. [7], Крикливець Д.Є. [8] та ін. вважають, що СС не є суб'єктом доказування.

Позиція Горбачевського В.Я. кореспондує з п. 6. ст. 22 КПК: суд... створює необхідні умови для реалізації сторонами їхніх процесуальних прав... [7, с. 244]. Крикливець Д.Є. слушно зауважує, що СС «своєю 
діяльністю не підміняе відповідних учасників кримінального провадження і лише може проявити активність у збиранні доказів за наявності сукупності 3-х факторів: а) одержання усного або письмового клопотання від учасника провадження; б) обгрунтування цим учасником неможливості самостійного забезпечення конкретного доказу; в) обгрунтування необхідності цього доказу» [8, с.14]. За КПК Федеративної Республіки Німеччина СС не є СД, а лише повинен перевірити чи дія, про яку йдеться в клопотанні прокурора, є допустимою 3 точки зору закону [5, с. 129].

В обгрунтування власної позиції - СС не є суб'єктом доказування відмітимо, що в ст. 93 КПК СС не віднесений до суб'єктів, які мають право збирати докази. Кримінально-процесуальні функції СС також не передбачають обов'язку доказування (ст. 92 КПК).

Деякі автори апелюють і вказують на закріплене в статтях 151, 156, $172,193,244$ КПК право СС «за клопотанням учасників розгляду або за власною ініціативою заслухати будь-якого свідка чи дослідити будь-які матеріали, що мають значення для вирішення клопотання». В даному випадку буква закону говорить про заслуховування, яке, на нашу думку, може стосуватися лише пояснень!, а не допиту. За змістом п. 8 ст. 95 КПК пояснення не є джерелом доказів. На відміну від допиту, заслуховування є пасивною дією. Дослідження [наданих сторонами] матеріалів, звичайно, не можна ототожнювати зі збором матеріалів оскільки СС не здійснює їх виявлення, фіксацію, вилучення.

Підняте питання має яскраво виразний процесуальний акцент i ставить під сумнів проведення заслуховування, допустимість отриманого пояснення як доказу та можливість його використання в подальшому доказуванні.

Чи може дух закону допустити вихід СС за визначені КПК виняткові правові можливості? Думається, що ні, оскільки застосування належної процедури є одним із складових елементів принципу верховенства права та передбачає, щоб повноваження суб'єктів були визначені приписами права і вони надалі діяли в межах наданих їм повноважень.

Згадуючи класифікацію СД зауважимо, що СС не має самостійного або представлюваного процесуального інтересу. Правова конструкція «за власною ініціативою» (активні дії) суперечить принципу неупередженості СС з огляду на відсутність обов'язку збирання доказів. Відтак ми вважаємо, що СС може лише сприяти учасникам в збиранні матеріалів для вирішення локального предмету доказування щодо заявлених клопотань. Нормативно це закріплено в згаданій раніше складовій принципу змагальності - суд створює необхідні умови для 164 
реалізації сторонами їхніх процесуальних прав (ч. 6 ст. 22 КПК). В переважній же більшості проваджень СС досліджує (перевіряє) і оцінює матеріали, подані сторонами.

3 цих же підстав ми не погоджуємося 3 думкою поважного процесуаліста Попелюшка В.О., який до розширеної класифікації повноважень СС, з урахуванням доказових можливостей «слабкої сторони», відніс «повноваження щодо збирання доказів у разі відмови слідчим, прокурором стороні захисту в задоволенні клопотання» [9, с. 10-16]. Для прикладу, у разі відмови слідчим захиснику в призначенні експертизи, останній, відповідно до ч. 1 ст. 244 КПК, має право звернутися до СС з аналогічним клопотанням. За результатами аналізу ${ }^{1}$, не виявлено ухвал про задоволення або відмову в задоволенні клопотань про призначення експертиз у кримінальних провадженнях про порушення прав інтелектуальної власності. Невикористання даного процесуального інституту у згаданій категорії проваджень на етапі досудового розслідування можна пояснити наявністю в матеріалах провадження майже обов'язкової (на цей час) економічної експертизи, отриманої стороною обвинувачення, або тактикою захисту, який просить призначити експертизу на

етапі судового розгляду в порядку ст. 333 КПК.

Також складно погодитись і з Гловюк І.В. стосовно повноважень СС самостійно забезпечувати докази шляхом «депонування показів» в порядку ст. 225 КПК. [10, с.305]. Із змісту ст. 225 КПК вбачається, що таку процесуальну дію СС не ініціює і не проводить самостійно, а лише за клопотанням сторони або представника юридичної особи, щодо якої здійснюється провадження. Отримані в порядку ст. 225 КПК покази проходять ще через два додаткові процесуальні фільтри:

положення ч. 3 ст. 225 КПК відповідно до яких суд може не врахувати докази, отримані в порядку, передбаченому цією статтею;

засада безпосередності дослідження доказів судом, для якого здобуті, в порядку ст. 225 КПК, покази не мають обов'язкової сили.

Аналі ${ }^{1}$ застосування інституту «депонування показів» у кримінальних провадженнях про порушення прав інтелектуальної власності не виявив ухвал про задоволення або відмову в задоволенні таких клопотань.

1 автором проаналізовано Єдиний державний реєстр судових рішень за період з 01.01.2010 р. по 01.01.2021 р. щодо кримінальних правопорушень, передбачених ст. 176, 229 КК України 
В контексті розгляду СС клопотань про надання дозволу на проведення НСРД слід підкреслити наступне. Розгляд клопотань взагалі не передбачає надання або витребування СС (не кажучи вже про збирання) нічого іншого, крім клопотання до якого додається витяг 3 ЄРДР (ч. 2 ст. 248 КПК).

В дискусії щодо ролі судових органів в процесі доказування Колесник В.А. висловив думку, яку ми підтримуємо: «Право на прийняття рішень, які визначають хід і послідовність проведення процесуальних дій під час досудового розслідування та використання отриманих результатів повинно належати процесуальним особам органу досудового розслідування, а не судовим органам» [6, с. 351$]$.

Вважаємо, що наведені аргументи підтверджують висунуту тезу - слідчий суддя не є суб'єктом доказування в кримінальному провадженні. Для забезпечення дієвості процесуальних норм та ефективного правозастосування, пропонуємо скорегувати конструкцію «заслухати будь-якого свідка».

\section{Література:}

1. Кримінальний процесуальний кодекс України URL: https:// zakon.rada.gov.ua/laws/show/4651-178\#Text

2. Гловюк І.В. Слідчий суддя у кримінально-процесуальному доказуванні Часопис Академії адвокатури України - № 3. 2013. С. 1-6.

3. Туманянц А.Р. Інститут слідчого судді за новим Кримінальним процесуальним кодексом України // Університетські наукові записки. 2013. - № 1. - С. 293-299.

4. Теорія судових доказів в питаннях та відповідях навч. посіб. / [Удалова Л.Д., Письменний Д.П., Азаров Ю.І. та ін.]. - К.: «Центр учбової літератури». 2021. - 104 с.

5. Сучасний кримінальний процес країн Європи : монографія [В.В. Луцик, В.А. Савченко, В.І. Самарін. - Харків : Право. 2018. $-792 \mathrm{c}$.

6. Колесник В.А. Слідчий суддя як суб'єкт прийняття рішення про проведення негласних слідчих (розшукових) дій URL: https://dspace.uzhnu.edu.ua/jspui/bitstream/lib/21773/1/

7. Горбачевський В.Я. Судовий контроль на стадії досудового розслідування // // Південноукраїнський правничий часопис. - 2014. № 3. - С. 243-246.

8. Крикливець Д. Є. Реалізація засади змагальності під час розгляду скарг слідчим суддею : дис. ... канд. юрид. наук : 12.00.09. Львівський національний університет ім. Івана Франка. Львів, 2016. 321 с. 
9. Попелюшко В.О. Слідчий суддя у кримінальному провадження // Часопис Національного університету «Острозька академія». Сер. Право. - 2014. - № 1. С. 1-30.

10. Гловюк І.В. Функціональна спрямованість діяльності слідчого судді // Ученые записки Таврического национального университета им. В.И. Вернадского Сер. Юридические науки. Том 26. 2013. № 2-1 (Ч.2). С. 303-309

\title{
DOI https://doi.org/10.30525/978-9934-26-116-9-41
}

\section{ЗАГАЛЬНІ ПОЛОЖЕННЯ ПРО ВТРУЧАННЯ У ПРИВАТНЕ СПІЛКУВАННЯ ЗА КРИМІНАЛЬНИМ ПРОЦЕСУАЛЬНИМ КОДЕКСОМ УКРАЇНИ}

\author{
Крет Г. Р. \\ доктор юридичних наук, доцент, \\ суддя Великої Палати Верховного Суду \\ м. Київ, Україна
}

У ст. 258 КПК України визначено загальні положення про втручання у приватне спілкування, які значною мірою грунтуються на відповідних положеннях Конституції України і міжнародних договорів, згода на обов'язковість яких надана Верховною Радою України, присвячених закріпленню права кожного на повагу до свого приватного та сімейного життя, до свого житла і кореспонденції (ст. ст. 31, 32 Конституції України [1], ст. 17 Міжнародного пакту про громадянські і політичні права від 16.12.1966 р. [2], ст. 8 Конвенції про захист прав людини і основоположних свобод від 04.11.1950 р. [3], ст. ст. 14, 15 та інші КПК [4]). 3 урахуванням положень наведених нормативноправових актів, право на повагу до приватного та сімейного життя, житла і кореспонденції не $є$ абсолютним та може зазнавати обмежень шляхом втручання в його здійснення (зокрема, обмеження таємниці листування, телефонних розмов, телеграфної та іншої кореспонденції, інших форм спілкування), з підстав і в порядку, встановлених законом.

Втручання може здійснюватися виключно у приватне спілкування, у зв'язку з чим у ч. 3 ст. 258 КПК законодавцем розмежовуються поняття спілкування та приватного спілкування. При цьому приватним спілкуванням, 3 огляду на ч. ч. 3 і 4 ст. 258 КПК, є передання 